\title{
COVID-19 and PM2.5 Sodium Chloride content
}

\section{ABSTRACT}

INTRODUCTION: Following national lockdown instituting physical distancing, COVID-19 infection and mortality decreased in most countries. Simultaneously due to diminished economic and human activity, the atmospheric levels of PM2.5, an important airborne pollutant, decreased significantly. COVID-19 has been found adherent to PM2.5. PM2.5 has various components including sodium chloride which determines the amount of PM2.5 salt-derived water content. Atmospheric salt content in part determines the sodium chloride content and the consequential hygroscopicity of PM2.5. COVID-19 possesses a C-terminal protein which is hydrophobic.

METHOD: The sodium chloride content of the PM2.5 species was assessed in two groups of cities. Cities were chosen as opposed to countries, because substantial regional differences in infection rates were noted between inland and coastal cities. These cities were differentiated by the rate COVID-19 infection and consequent mortality. Atmospheric salt content was obtained from research that assessed chloride ion wet deposition, a proxy for airborne salinity. The salt content of the relevant PM2.5 species was obtained from publications from the various cities assessed.

RESULTS: Cities with high COVID-19 infection rates had PM2.5 species with significantly lower salt content than the cities with low Covid-17 infection. The PM2.5 salt content in the cities with elevated COVID-19 rates was $0.196 \mu \mathrm{g} / \mathrm{m}^{3} \mathrm{SD}$ $0.05 \mu \mathrm{g} / \mathrm{m}^{3}$, while cities with low COVID-19 rates had a PM2.5 salt content of $0.81 \mu \mathrm{g} / \mathrm{m}^{3}$ SD $0.32 \mu \mathrm{g} / \mathrm{m}^{3}(\mathrm{p}<0.0001)$.

There was a significant correlation between atmospheric salinity and the salt content of PM2.5. PM2.5 salt content correlated with minimum atmospheric salinity $(\mathrm{R}=0.53$, $\mathrm{p}<0.01)$ and maximum atmospheric salinity $(\mathrm{R}=0.64, \mathrm{p}<0.002)$.

There appears to be an inverse relationship between COVID-19 infection and atmospheric salt content levels. Cities that were spared high COVID-19 infection rates, have higher maximum/minimum atmospheric salinity content levels (216-1080 $\mathrm{mgCl} / \mathrm{m}^{2} /$ day) compared to sodium chloride levels noted in cities with high COVID19 rates of infection $\left(40-125 . \mathrm{mgCl} / \mathrm{m}^{2} /\right.$ day $)(\mathrm{p}<0.005)$.

CONCLUSION: PM2.5 with low salt content, in the presence of low ambient salinity may be linked to an increased risk of COVID-19 infection in the population.

Keywords: COVID-19, PM2.5 sodium chloride, atmospheric salt content.

\section{INTRODUCTION}

COVID-19 infection appears to be decreasing in most countries. This decrease is attributed to the social distancing legally enforced in most countries. Concomitant with the reduction in COVID-19 infection incidence, a significant decrease in pollution, including PM2.5 levels, were noted ${ }^{1,2,3}$. A significant reduction in COVID19 related mortality was also noted in relation to a reduction in PM2.5 ${ }^{4}$ There are 
some countries and cities which appear to have contained the infection prior and after lockdown, including Malta, Hong Kong, Cyprus, South Korea, Australia, New Zealand and Taiwan ${ }^{5,6}$.

There are factors in common to the countries which appear to have contained the COVID-19 pandemic. Geographical isolation, whereby most of these countries are in fact islands, may have prevented large population movements which encourage mass spread of infection - physical distancing on a national scale. Legal implementation of social distancing in small isolated populations may be easier to enforce. Legislation enforcing public health measures such as physical distancing and procedures to protect the elderly and vulnerable individuals may be more effective ${ }^{7}$.

Concomitant with social distancing a reduction in human mobility and economic activity resulted. The reduction in activity in turn led to significant diminution in pollution including PM2.5 levels ${ }^{1,2,3}$. There lies the possibility that besides, the undoubtedly effective measures of physical distancing at reducing viral transmission, there may be environmental factors including the level and composition of the pollutant PM2.5 that may impact COVID-19 infection.

COVID-19 has been found adherent to PM2.5 $5^{8}$ Atmospheric salinity determines the PM2.5's sodium chloride component which in turn determines the water content of PM2.5 ${ }^{9}$. The C-terminal of a viral fusion peptide is strongly hydrophobic ${ }^{10,11}$ and the water content of PM2.5 may act as a deterrent to COVID-19 adhesion to this particulate matter.

\section{METHODOLOGY}

The salt content of particulate matter PM2.5 and atmospheric salt content were assessed from a number of cities, differentially affected by COVID-19 infection. Cities were selected as opposed to countries, because substantial regional differences in infection rates have noted especially between inland and coastal cities ${ }^{12}$. The cities chosen to be assessed were divided into two groups. The first group (Group 1) included Wuhan, Qom, Bergamo, Madrid, New York, Limburg (Vredepeel), Atlanta, and Pretoria, all having significantly high rates of COVID-19 infection, compared to other cities in their respective countries. Group 2 consisted of cities including Seoul, Hanoi, Rehovot, Buenos Aires, Singapore, Beijing, Kanpur, Dhaka, Taipei, Rotterdam, Hong Kong and Malta, all of which have very low rates of COVID-19 infection $^{12}$. An important caveat is that infection and mortality rates very much depend on the level of COVID-19 testing in the individual populations.

The level of atmospheric salt content may be inferred from the chloride ion wet deposition index measured as $\mathrm{mgCl} / \mathrm{m}^{2} /$ day. Atmospheric salt content levels were obtained from an indexed colour coded map compiled by Fraunhofer ISE, through a site set up by the Galvanizers Association ${ }^{13}$. This map determines the level of salt content in different regions in the world in connection with the risk of automobile corrosion. The data are represented as maximum and minimum levels per day 


\section{RESULTS}

There was a significant difference in the salt content of PM2.5 between both groups of cities. Cities with low COVID-19 infection rates had significantly higher salt content in the PM2.5, compared to the cities with high levels of COVID-19 infection. The PM2.5 salt content in the cities with high COVID-19 rates was $0.196 \mu \mathrm{g} / \mathrm{m}^{3} \mathrm{SD}$ $+/-0.05 \mu \mathrm{g} / \mathrm{m}^{3}$, while cities with low COVID-19 infection rates had a PM2.5 salt content of $0.81 \mu \mathrm{g} / \mathrm{m}^{3} \mathrm{SD}+/-0.32 \mu \mathrm{g} / \mathrm{m}^{3}(\mathrm{p}<0.0001)$.

The cities that seem to have contained the pandemic are close or surrounded by sea, and consequently have an elevated atmospheric salt content. Cities that evaded high COVID-19 infection rates have higher atmospheric salt content levels, minimum/maximum $216-1080 \mathrm{mgCl} / \mathrm{m}^{2} /$ day compared to minimum/maximum 40 $125 \mathrm{mgCl} / \mathrm{m}^{2} /$ day $(\mathrm{p}<0.005)$ noted in cities sustaining high COVID-19 rates of infection.

Normality plots applied to the PM2.5 salt content showed parametric patterns allowing the application of the T-Test. Both the maximum and minimum atmospheric salt content levels were nonparametric whereby the Mann -Whitney U test was applied. Spearman Rank test was applied to assess statistical correlations to nonparametric variables.

The results are demonstrated in two tables designated Figure 1. and Figure 2.

$\underline{\text { Cities with high COVID-19 infection rates }}$

$\begin{array}{lccc}\text { Salt Content } & \begin{array}{c}\text { Minimum Chloride Ion } \\ \mu \mathrm{g} / \mathrm{m}^{3}\end{array} & \begin{array}{c}\text { Maximum Chloride Ion } \\ \text { Deposition } \mathrm{mgCl} / \mathrm{m}^{2} / \text { day }\end{array} \\ \text { Wuhan } & 0.3 & 4 & 60 \\ \text { Qom } & 0.19 & 4 & 60 \\ \text { Bergamo } & 0.2 & 61 & 300 \\ \text { N. York } & 0.2 & 61 & 300 \\ \text { Madrid } & 0.2 & 61 & 300 \\ \text { Atlanta } & 0.1 & 61 & 301 \\ \text { Pretoria } & 0.2 & 4 & 60 \\ \text { Limburg } & 0.2 & 61 & 301\end{array}$

Cities with low COVID-19 infection rates

$\begin{array}{lccc} & \begin{array}{c}\text { Salt Content in } \\ \mathrm{PM} 2.5 \mu \mathrm{g} / \mathrm{m}^{3}\end{array} & \begin{array}{c}\text { Minimum Chloride Ion } \\ \text { Deposition } \mathrm{mgCl} / \mathrm{m}^{2} / \text { day }\end{array} & \begin{array}{c}\text { Maximum Chloride Ion } \\ \text { Deposition } \mathrm{mgCl} / \mathrm{m}^{2} / \text { day }\end{array} \\ \text { Malta } & 0.62 & 300 & 1500 \\ \text { Seoul } & 0.63 & 300 & 1500 \\ \text { Taipei } & 1.1 & 300 & 1500\end{array}$




$\begin{array}{lccc}\text { HongKong } & 0.46 & 300 & 1500 \\ \text { Singapore } & 1.1 & 61 & 301 \\ \text { Kanpur } & 0.6 & 4 & 60 \\ \text { Beijing } & 1.3 & 300 & 1500 \\ \text { Dhaka } & 1.4 & 300 & 1500 \\ \text { B. Aires } & 0.6 & 61 & 301 \\ \text { Rotterdam } & 0.4 & 300 & 1500 \\ \text { Hanoi } & 0.9 & 61 & 301 \\ \text { Rehovot } & 0.9 & 300 & 1500\end{array}$

Fig. 1. There was a significant difference in the salt content of PM2.5 between both groups of cities $\mathrm{p}<0.0001$. Atmospheric salt content in $\mathrm{mgCl} / \mathrm{m}^{2} /$ day indicating minimum and maximum levels compared to salt content in PM2.5 species in different cities. The $\mathrm{p}$ value for the atmospheric salt content between the two groups of cities is $\mathrm{p}<0.005$. References for salt content inPM2. $5^{9,14-22}$

$\underline{\text { Correlation between PM2.5 content and Atmospheric salt content }}$

$\begin{array}{lccc} & \begin{array}{c}\text { Salt Content in } \\ \mathrm{PM} 2.5 \mu \mathrm{g} / \mathrm{m}^{3}\end{array} & \begin{array}{c}\text { Minimum Chloride Ion } \\ \text { Deposition } \mathrm{mgCl} / \mathrm{m}^{2} / \text { day }\end{array} & \begin{array}{c}\text { Maximum Chloride Ion } \\ \text { Deposition } \mathrm{mgCl} / \mathrm{m}^{2} / \text { day }\end{array} \\ \text { Malta } & 0.62 & 300 & 1500 \\ \text { Seoul } & 0.63 & 300 & 1500 \\ \text { Taipei } & 1 & 300 & 1500 \\ \text { HongKong } & 0.46 & 300 & 1500 \\ \text { Singapore } & 1.1 & 61 & 301 \\ \text { Kanpur } & 0.6 & 4 & 60 \\ \text { Beijing } & 1.3 & 300 & 1500 \\ \text { Dhaka } & 1.4 & 300 & 1500 \\ \text { B. Aires } & 0.6 & 61 & 301 \\ \text { Rotterdam } & 0.4 & 300 & 1500 \\ \text { Hanoi } & 0.9 & 61 & 301 \\ \text { Rehovot } & 0.9 & 300 & 1500 \\ \text { Wuhan } & 0.3 & 4 & 60 \\ \text { Qom } & 0.19 & 4 & 60 \\ \text { Bergamo } & 0.2 & 61 & 300 \\ \text { New York } & 0.2 & 61 & 300 \\ \text { Madrid } & 0.2 & 61 & 300 \\ \text { Atlanta } & 0.1 & 61 & 301 \\ \text { Pretoria } & 0.2 & 61 & 301 \\ \text { Limburg } & 0.2 & 61 & 301 \\ & & & \end{array}$

Fig. 2. The salt content of PM2.5 in both groups of cities correlated with the Atmospheric salt content. Correlation between minimum chloride ion deposition 
versus salt content in PM2.5 R-value $=0.56,(p<0.01)$. Correlation between maximum chloride ion deposition versus salt content in PM2.5 $\mathrm{R}=0.64$, $(\mathrm{p}<0.002)$. References for salt content inPM2. $5^{9,14-22}$

\section{DISCUSSION}

Undoubtedly reduced transmission of COVID-19 followed the institution of social distancing. Besides reducing human to human viral transmission, physical distancing diminished levels of human and economic activity with consequential reduced pollution levels ${ }^{2}$. Coal consumption in China after lockdown decreased by approximately $50 \%$, from 80 thousand tonnes daily to 40 thousand tonnes per day $^{23}$. In India, reductions of the order of $43 \%$ and $31 \%$ were noted for PM2.5 and PM10 respectively, during lockdown period compared to previous years. During the same period carbon monoxide decreased by $10 \%$ and nitrous oxide decreased by $18 \%$. The air quality index (AQI) improved throughout India following lockdown ${ }^{24}$.

Before statutory lockdown, there may have been synergism between high PM2.5 levels and COVID-19 in infection transmission. This synergism may have also determined the severity of COVID-19 sequelae. Pathological synergism between PM2.5 and respiratory infection has been shown in animal studies. Preclinical studies, exposing mice to cigarette smoke demonstrated that following intratracheal injection of streptococcus pneumoniae, bacterial counts in murine lungs were higher than the control group ${ }^{25}$. Another study showed that air pollution could result in dysfunction of rat tracheal cilia, causing mucus stasis and resultant infection. Moreover a declined nonspecific immune defense, was noted making the rats more prone to secondary infection $^{26}$. Viability and phagocytic activity of alveolar macrophages decreased significantly following the instillation of PM2.5 particles in Wistar rats ${ }^{27,28}$.

Similar deleterious effects of PM2.5 have been found in the respiratory system of humans. PM2.5 releases free radicals, metal and the organic components inducing free radical production leading to oxidation of lung tissue ${ }^{29}$. Through PM2.5's propensity to produce free radicals, peroxidation of lipids on the cell membrane occurs, with consequent elevation of intracellular calcium. High levels of intracellular calcium increases inflammatory cytokine production (Kim et al 1997). PM2.5induced inflammation led to an increase in the number of neutrophils, eosinophils, T cells and mastocytes ${ }^{30.31}$. All these cells can result in inflammatory cytokine production and resultant cytokine storm has been responsible for a significant number of COVID-19 related deaths ${ }^{32}$

Addressing this synergism may protect the populations from airborne infections such as the COVID-19 infection and simultaneously foster respiratory health. Prior to the outbreak of COVID-19 in Wuhan, Qom and Bergamo the Air Quality Index demonstrated strikingly elevated pollution levels of PM2.5 $5^{33}$. These elevated levels of PM2.5 occurred during the winter months possibly due to combustion of fuel for residential heating purposes. 
Inferring from the fact that coastal cities have been in the main been spared from high COVID-19 infection, another environmental factor may come into play in the form of the level of atmospheric salt content. Chloride ion wet deposition, a variable reflecting the ambient salinity could be obtained from a colour-coded map of the distribution of the earth's salt content. ${ }^{13}$

Wuhan has been noted to be one of the cities in China with the least salt content in the air $^{14}$. The cities hard hit by COVID-19 infection are distant from the sea and consequently have low salt content levels ${ }^{14-22}$. Rotterdam with an elevated salt content PM2.5 $\left(0.4 \mu \mathrm{g} / \mathrm{m}^{3}\right)$ had lower rates of COVID-19 compared to Vredepeel in the inland Limburg region $\left(0.2 \mu \mathrm{g} / \mathrm{m}^{3}\right)$. Beijing with a high salted PM2.5 $\left(1.3 \mu \mathrm{g} / \mathrm{m}^{3}\right)$ had lower levels than Wuhan $\left(0.3 \mu \mathrm{g} / \mathrm{m}^{3}\right)$. It is imperative that the impact of physical distancing due to enforced quarantine be factored in when considering infection rates. South West region of the U.K. with higher saline levels had lower COVID-19 infection rates compared to London which appears to have a lower chloride ion wet deposition. Similarly in Italy whereby the saline deficient Lombardy region was severely affected by COVID-19 infection, while the more saline rich south of Italy have very low infection rates.

Healthy levels of airway salt content protect the respiratory system disease. Hypertonic saline has been shown to have anti-infective properties ${ }^{34}$. Tracheobronchial ciliary action is accentuated when the saline content of the endobronchial tree is optimal. Optimal levels of tracheal sodium chloride are mucolytic making bronchial mucus is less viscous with. Patients with respiratory condition such as asthma and cystic fibrosis benefit from endo-bronchially nebulized saline ${ }^{35}$

A protein component of COVID-19 virus is hydrophobic ${ }^{10,11}$. Viral cell entry is mediated through extensive post-receptor-binding structural readjustments on the cell membrane. The hydrophobic peptides include the C-terminal of a fusion peptide $^{11,12}$. Low concentrations of chlorinated solutions are lethal to the virus ${ }^{37}$. Atmospheric salt content may be another environmental factor that may have protected some populations preventing airborne infection from the COVID-19.

Variable amounts of sodium chloride are found on PM2.5 species ${ }^{9}$. The PM2.5 species vary from city to city, and there are also seasonal changes in the sea salt component of the PM2.5. As a corollary to the variable amount of PM2.5 sodium chloride component, there also a variable degree of hygroscopicity related to the sea salt-derived water content ${ }^{9}$. Besides the lethal effect of sodium chloride on the virus, there may be a connection with aerosol adhesion due to sodium chloride with the pollutant PM2.5. Recent evidence suggests that COVID-19 may adhere to PM2.5 particles to evade the bronchial tree defences and colonize the alveoli ${ }^{8}$. The presence of hygroscopic sodium chloride on PM2.5 may act as a deterrent against the adhesion of the hydrophobic proteins of COVID-19 to these particles, protecting populations living in regions with salt-rich PM2.5 prevalent high salt content regions.

CONCLUSION: The COVID-19 pandemic may have occurred due to the combination of a number of environmental factors besides the virulence of the virus. A decrease in airborne pollution in particular PM2.5 and possibly the sodium chloride 
rich species of PM2.5 may have protected some populations from the COVID-19 pandemic.

\section{References}

1. Bao R and Zhang A, Does lockdown reduce air pollution? Evidence from 44 cities in northern China. Sci Total Environ. 2020 Apr 29 : 139052. doi: 10.1016/j.scitotenv.2020.13905.

2. Wang Q and Su M. A preliminary assessment of the impact of COVID-19 on environment - A case study of China. Sci Total Environ. 2020 Aug 1; 728: 138915. Published online 2020; 22. doi: 10.1016/j.scitotenv.2020.138915

3. Muscat Baron Y. COVID-19 Pandemic in relation to Pollution due to PM2.5 and Atmospheric salt content. An Environmental Wake-up Call. 2020. www.medrxiv.org.

4. Wu X, Nethery RC, Sabath B, Braun D, Dominici F Exposure to air pollution and COVID-19 mortality in the United States: A nationwide cross-sectional study Department of Biostatistics, Harvard T.H. Chan School of Public Health, Boston. 2020 www.medrxiv.org

5. Cristian Ilie P, Stefanescu S, Smith L. The role of vitamin D in the prevention of coronavirus disease 2019 infection and mortality. Aging Clin Exp Res. 2020 May $6: 1-4$. doi: 10.1007/s40520-020-01570-8.

6. Baker M, Kvalsvig A, Verrall M, Telfar-Barnard L, Wilson N. New Zealand's elimination strategy for the COVID-19 pandemic and what is required to make it work. 2020: Vol 133 No 1512: 3.

7. Gostin LO, Burris S, Lazzarini Z. The law and the public's health: a study of infectious disease law in the United States. Columbia Law Rev. 1999 Jan;99(1):59-128.

8. Setti L, Passarini L:, De Gennaro G, Baribieri P et al. SARS-Cov-2 RNA Found on Particulate Matter of Bergamo in Northern Italy: First Preliminary Evidence. PRISCO PISCITELLI, Alessandro Miani. www.medrxiv.org 2020

9. Snider C L, Weagle K, Murdymootoo Y et al Variation in Global Chemical Composition of PM2.5: Emerging Results from SPARTAN.February 2016. Atmospheric Chemistry and Physics. Aerosols and Climate Surface Particulate Matter Network (SPARTAN).

10. Robson B. COVID-19 Coronavirus spike protein analysis for synthetic vaccines, a peptidomimetic antagonist, and therapeutic drugs, and analysis of a proposed achilles' heel conserved region to minimize probability of escape mutations and drug resistance. Comput Biol Med2020 Apr $11: 103749$. doi: 10.1016/j.compbiomed. 2020.103749.

11. Aydin H, Al-Khooly D, Lee JE. Influence of hydrophobic and electrostatic residues on SARS-coronavirus S2 protein stability: insights into mechanisms of general viral fusion and inhibitor design. Protein Sci. 2014;23(5):603-17. doi: $10.1002 /$ pro. 2442 .

12. World Health Organization. Infection prevention and control during health care when COVID-19 is suspected https://www.who.int/publications- 
detail/infection-prevention-and-control-during-health-care-when-novelcoronavirus-(ncov)- infection-is-suspected-20200125

13. Poma J. Salt Air: How far inland does salty air affect metals? 2018 Galvanizers Association.

14. Li R, Cui L, Zhao Y, Zhang Z, Sun T, Li J, Zhou W, Meng Y, Huang K, and $\mathrm{Fu} \mathrm{H}$ Wet deposition of inorganic ions in 320 cities across China: spatiotemporal variation, source apportionment, and dominant factors. 2019;19:11043-1070 Atmospheric Chemistry and Physics.

15. Nadali A, Arfaeinia H, Asadgol Z, Fahiminia M. Indoor and outdoor concentration of PM 10, PM 2.5 and PM 1 in residential building and evaluation of negative air ions (NAIs) in indoor PM removal. $2020 \underline{10.1080 / 26395940.2020 .1728198}$

16. Perrone MR, Carofalo I, Dino A. Ionic and elemental composition of TSP, PM10 and PM2.5 over Italy. 2009 Il Nuovo Cimento 124(3): 341-356.

17. Querol X, Alastuey A, Moreno T. Atmospheric Particulate Matter in Spain.

18. Balzan M, Cibella F, Zammit C,Chemical fingerprint of outdoor PM2. 5 in Malta Eur Respiratory Soc. 2015.

19. Heom J, Hopke PK, Yi SM. Source apportionment of PM2.5 in Seoul, Korea Atmospheric Chemistry and Physics 2009(14):4957-4971. DOI: 10.5194/acp9-4957-2009

20. Zhang R, Jing J, Tao J et al. Chemical characterization and source apportionment of PM2.5 in Beijing: seasonal perspective. Atmos. Chem. Phys., 13, 7053-7074, 2013.

21. Leea SC, Watson JG, Chow JC et al, Feasibility of Establishing Air Monitoring Supersites in Hong Kong 2009.

22. Manders AMM, Schaap M, Jozwicka M et al, Netherland Environmental assessment Agency. The contribution of sea salt to PM10 and PM2.5 in the Netherlands. ISSN: 1875-2322 (print) ISSN: 1875-2314 (on line)

23. Ghosh I. 2020. These Satellite Photos Show how COVID-19 Lockdowns Have Impacted Global Emissions: https: //www.

weforum.org/agenda/2020/03/emissions-impact-coronavirus-lockdownssatellites/.

24. Sharma S, Zhang M, Gao J, Zhang H and Kota SH. Effect of restricted emissions during COVID-19 on air quality in India. Sci Total Environ. 2020 Aug 1; 728: 138878. Published online 2020 Apr 22. doi: $10.1016 /$ j.scitotenv.2020.138878

25. Phipps JC, Aronoff DM, Curtis JL, et al. Cigarette smoke exposure impairs pulmonary bacterial clearance and alveolar macrophage complement-mediated phagocytosis of Streptococcus pneumoniae. Infect Immun 2010;78:1214-20.

26. Phipps JC, Aronoff DM, Curtis JL, et al. Cigarette smoke exposure impairs pulmonary bacterial clearance and alveolar macrophage complement-mediated phagocytosis of Streptococcus pneumoniae. Infect Immun 2010;78:1214-20.

27. Zhou Y, Wang RQ, Zhao S, et al. Effect on cytokines and ultrastructure in rats exposed to mixed air pollutants. Journal of Shenyang Medical College 2009;11:6-12.

28. Jalava PI, Salonen RO, Pennanen AS, et al. Heterogeneities in inflammatory and cytotoxic responses of RAW 264.7 macrophage cell line to urban air coarse, fine, and ultrafine particles from six European sampling campaigns. Inhal Toxicol 2007;19:213-25. 
29. Huang NH, Wang Q, Xu DQ. Immunological effect of PM2.5 on cytokine production in female Wistar rats. Biomed Environ Sci 2008;21:63-8.

30. Kim YK, Jung JS, Lee SH, et al. Effects of antioxidants and $\mathrm{Ca} 2+$ in cisplatininduced cell injury in rabbit renal cortical slices. Toxicol Appl Pharmacol 1997;146:261-9.

31. Sigaud S, Goldsmith CA, Zhou H, et al. Air pollution particles diminish bacterial clearance in the primed lungs of mice. Toxicol Appl Pharmacol 2007;223:1-9.

32. Gripenbäck S, Lundgren L, Eklund A, et al. Accumulation of eosinophils and T-lymphocytes in the lungs after exposure to pinewood dust. Eur Respir J 2005;25:118-24.

33. Nile SH Arti Nile A, Jiayin Qiu et al. COVID-19: Pathogenesis, cytokine storm and therapeutic potential of interferons. Cytokine Growth Factor Rev. 2020 doi: 10.1016/j.cytogfr.2020.05.002.

34. World's Air Pollution: Real-time Air Quality Index. http//aqicn.org/contact/

35. Reeves EP, Molloy K, Pohl K, and McElvaney NG. Hypertonic Saline in Treatment of Pulmonary Disease in Cystic Fibrosis. ScientificWorldJournal. 2012; 2012: 465230. Published online 2012 May 3. doi: 10.1100/2012/465230

36. Donaldson H, Bennett P, Zeman, KL, et al. Mucus Clearance and Lung Function in Cystic Fibrosis with Hypertonic Saline Scott N Engl j med 354;3 www.nejm.org 2006

37. Bender L. Key Messages and Actions for COVID-19 Prevention and Control in Schools. Education in Emergencies UNICEF March 2020.

1. www.ceic.data.com China National Environmental Monitoring Centre 
